\title{
The Effect of Corporate Governance on Firms' Capital Structure of Listed Companies in Sri Lanka
}

\author{
- Bulathsinhalage Siromi, Pathirawasam Chandrapala
}

\begin{abstract}
There is a great awareness among the researchers to carry out researches on corporate governance and it contributes to the firms' competitive advantage and business success. In today's turbulent economic environment, competitiveness has become more important than ever for a firm's survival and success. However, there is a gap in studies focusing on corporate governance and capital structure in the context of Sri Lanka. The aim of this study is to empirically investigate whether attributes of corporate governance affect decisions on capital structure of listed companies in Sri Lanka. The sample of the study consisted of 138 non-financial listed companies for five-year period from 2009 to 2013. Board size, board composition, leadership structure, board committees, and managerial ownership were used as corporate governance variables whereas debt ratio as the measure of capital structure and return on assets (ROA) and firm size as control variables.

The variables were empirically tested by multiple regression analysis. The findings revealed that there is no significant effect of corporate governance attributes except board composition \& board committee on capital structure. The variable of board composition has a significant positive effect and board committee has a negative effect on capital structure.
\end{abstract}

Keywords: corporate governance, capital structure, debt ratio, Colombo Stock Exchange (CSE), multiple regression analysis

JEL Classification: $G 32$

\section{INTRODUCTION}

Corporate governance has become an international issue due to globalization of businesses. It is concerned with ways in which all parties involved in the well-being of the organization attempt to ensure that mangers and other insiders take measures or adopt mechanisms that protect the interests of the stakeholders.

There is no globally accepted set of corporate governance principles that can be applied to board structures, as they depend on business practices and economic environment of the countries. Developing countries differ compared to developed countries in a wide variety of ways. Hence, it is essential for developing countries to develop their own corporate governance models according to their cultural, political and technological conditions (Mulili \& Wong, 2011).

During the past few years, there has been a growing awareness of corporate governance in Sri Lanka. As a consequence of that, it is now mandatory for companies to comply with the corporate governance rules that formed part of the listing rules of the Colombo Stock Exchange 
(CSE), which took effect from the April 2008. As a result of that, it is needed to assess the implementations and practices of corporate governance by the listed companies in Sri Lanka and the identification of its impact on various imperative fields such as firms' performance and capital structure.

The optimal mix of debt and equity financing decisions are crucial to success of the companies (Graham \& Harvey, 2001 and Bancel \& Mitto, 2004). Even though there is a growing body of literature on corporate governance practices and capital structure, there is a diversity of results due to the different theoretical perspectives applied, selection of methodologies, measurement of variables, conflicting views on board involvement in decision making and the contextual nature of individual firms (shafana, 2016). A prior research on relationship between the corporate governance and the capital structure has been done in the developed countries, but a few studies have been carried out in the emerging countries (Ahmadpour et al. 2012).

In the Sri Lankan context, most researches had made their studies focusing on firms' performance. (Kajananthan, 2012) Few researchers have paid their attention to the impact of corporate governance on firms' capital structure; even those studies also based on limited selected corporate governance variables and sample companies and findings are contradictory. According to Heenetigala (2011), it was suggested that future research should be carried out with a larger sample after the introduction of the mandatory code of best practice in 2008. So, the effect of corporate governance on firm's capital structure is still inconclusive.

Therefore, the main objective of this study is to empirically examine the effect of the components of corporate governance on capital structure decisions of the listed companies in Sri Lanka. In addition to that, to identify the corporate governance practices of the listed companies in Sri Lanka and to analyze the changes in corporate governance practices between 2009 (with the introduction of code of best practices in 2008) and 2013 (after five year period).

\section{LITERATURE REVIEW}

\subsection{Corporate Governance}

Cadbury (1992) defined corporate governance as "the system by which companies are directed and controlled". It is concerned with the duties and responsibilities of a company's board of directors to successfully lead the company, and their relationship with its shareholders and other stakeholder groups (Pass 2004). According to Spanos (2005), "corporate governance is considered as having significant implications for the growth prospects of an economy, as best practice corporate governance reduces risks for investors, attracts investment capital and improves the performance of companies".

The corporate governance may be beneficial to the stakeholders as well as broader industries and economic sectors. Benefits to stakeholders include resolving conflicts of interest, instilling controls and a sense of ethics, and enforcing and encouraging transparency. According to Thomson \& Bereau (2009) fundamentally, there is a level of confidence that is connected with a company that is known for having good corporate governance. The existence of an active group of independent directors on the board contributes greatly to ensuring confidence in the market, and 
the corporate governance has been identified as the criteria that foreign institutional investors are increasingly depending on when deciding on which companies to invest in. It is also known for having a positive influence on the share price of the company. Having a clear image on the corporate governance front could also make it easier for companies to source capital at more reasonable cost (Thomson \& Bereau, 2009). According to this, corporate governance can be identified as the important concept not only to the stakeholders, but also to the whole economy. Similar to that, according to Keong (2002), good corporate governance brings better management and prudent allocation of the company's resources, and enhances corporate performance which would significantly contribute to the company's share price, increasing the value of a shareholder's holdings.

\subsection{Corporate Governance in Sri Lanka}

According to Sobhan \& Wendy (2003), in Sri Lanka, the concern for corporate governance originated from the failures of many finance companies in the late 1980's and early 1990's, which made investors lose faith in the regulatory and semi- regulatory frameworks as well as the standards of financial reporting.

Corporate governance initiatives in Sri Lanka started in 1997 with the introduction of a voluntary code of best practice on matters relating to the financial aspects of corporate governance. In 2003, voluntary codes of best practices on corporate governance were issued and after that according to Sri Lanka code of best practice on corporate governance (2008), standards were made mandatory for all listed companies for the financial year commencing on or after 1st April 2008. This code covers effectiveness of the board, separation of the position of CEO and the chairman, appointment of the chairman, non-executive directors, professional advice, director's training, directors responsibility for the presentation of financial statements, compliance reporting, internal control and committee structures for boards, including audit committee, remuneration committee and nomination committee.

\subsection{Corporate Governance and Capital Structure}

The capital structure decision is a vital one since the profitability of a company is directly affected by such decision (Kajanathan, 2012). According to Velnampy \& Aloy Niresh (2012), a successful selection and use of capital is one of the key elements of the firms' financial strategy. Colombage (2007) states that the existence of a well-developed capital market, financial intermediary, corporate governance and the legal protection offered by a country assist the effectiveness of debt.

According to Velnampy (2006), "the financial condition of a business organization would depend on the resources it owns and the obligations it has to meet. Companies carry out various activities to make profits and to generate wealth for further growth. Finance is considered as the most important for these activities". On the other hand, as per Kajanathan (2012), with the recent development of corporate governance practices and regulatory framework in Sri Lanka, it may influence on capital structure choice and decisions in the listed manufacturing companies.

In addition to that Claessens et al. (2002) argue that good corporate governance mechanisms help firms through a better access to financing and a lower cost of capital. 
However, the relationship between corporate governance and capital structure has not been fully explored. Only few studies have been made to identify this relationship and the findings are contradictory. (Hasan and Butt, 2009).

Kajanathan (2012) found that corporate governance practices had 34\% impact on the capital structure of Sri Lankan listed manufacturing companies and among corporate governance variables, a board committee has a significant impact on firms' capital structure. These results were supported by Achchuthan et al. (2013). The study revealed that board committee is positively significant for the capital structure, while board composition, board size and leadership style have no significant impact on the capital structure. Somathilake and Udaya kumara (2015) also examined the relationship between corporate governance and capital structure, and found that board composition has a significant impact on the capital structure. Ajanthan (2013) investigated whether there is any relationship among some specific characteristics of corporate governance and the capital structure and profitability of selected hotels and restaurant companies in Sri Lanka. The results revealed that the selected corporate governance characteristics have significant relationship with a capital structure and profitability. Wellalage and Lock (2012) found out that insider ownership, CEO duality and non-executive directors have a significant impact on the capital structure. Further, board size and ownership type have no significant impact on the capital structure.

However, Peiris and Fernando (2013) stated that, corporate governance characteristics have no significant effect on the capital structure decisions of non- financial companies in Sri Lanka. Similar to that, Ravivathan \& Danoshand, (2014) also found out that corporate governance characteristics have no significant impact on the capital structure.

\section{AIM AND METHODOLOGY}

The aim of the study was to test the effect of corporate governance practices on firms' capital structure, the design of the methodology was based on prior research into these relationships.

\subsection{Conceptualization}

Based on the purpose of the study, the conceptual model shown in Fig. 1 has been constructed. This model of corporate governance and capital structure presents new constructs and uniquely combine them in specifying that the capital structure is a function of Board size, CEO duality, Board composition, Board committees and managerial ownership. 


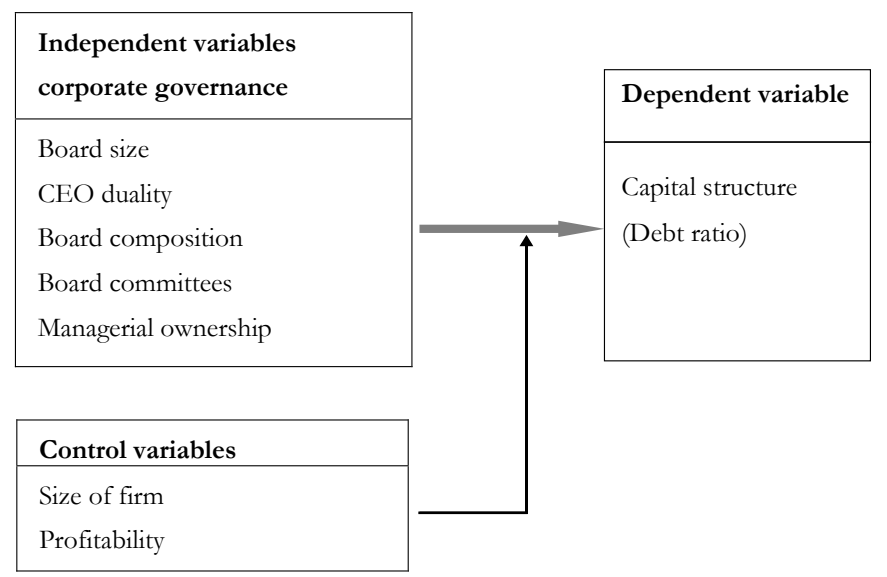

Fig. 1 - proposed research model. Source: own

\subsection{Research hypothesis}

\section{Board size and CEO duality}

The boards of directors are responsible for managing firm's activities and making strategic decisions. However, the empirical evidence of direction of the association between board size and capital structure is mixed. Bodaghi \& Ahmadpour (2010); Vakilifard et al. (2002); Hasan \& Butt (2009) and Magdalena (2012) found a significant negative association between board size and debt-to-equity ratio. This means that firms with a large board of directors generally have low debt-equity ratios. Berger et al. (1997) argue that large boards exert pressure on managers to follow lower debt -to-equity ratio and enhance firm's performance.

On the other hand, a positive and statistically significant relationship is found by Abor (2007); Ahmadpour et al. (2012); Saad (2010); Gill et al. (2012); Ganiyui \& Abiodun (2012) and Sheikh \& wang (2012). In the Sri Lankan context, Kajanathan (2012) and Wellalage \& Locke (2012) found a positive relationship between the board size and Leverage.

The evidence regarding relationship between the leadership structure (CEO duality) and company capital structure is mixed and inconclusive. Abor (2007) found that Ghanaian listed companies pursue high debt policies with CEO duality. Similarly, Vakilifard et al. (2011) argue that duality leadership firms have high debt to equity ratio. A possible explanation for this is that duality leadership reduces problems related to separation of ownership and control. Therefore, according to Wellalage \& Lock (2012) indicates that CEO duality increases firm debt usage. This may be based on stewardship theory that $\mathrm{CEO}$ duality reduces communication conflicts in uncertain environments and creates a clear sense of strategic decision. Therefore, duality leadership leads to Sri Lankan companies having high debt policies.

So, a testable hypothesis regarding board size and CEO duality with company debt ratio is:

H1: In Sri Lanka, board size and board leadership structure (CEO duality) are positively associated with a company debt ratio. 


\section{Non-executive directors and board committees}

Non-executive directors play supervisory and balancing roles, controlling the activities of the executive directors and the board in general (Waduge, 2010). Sri Lanka's code of best practice on corporate governance (2008) recommended boards including at least two non-executive directors, or that non-executive directors make up one third of the board. Abor (2007), Sheikh \& Wang (2012) and Kajanathan (2012) find a significant positive relationship between percentage of non-executive directors' in the board and firm leverage ratio. This indicates that outside directors have a positive impact on the corporate leverage. One possible explanation of this is that non-executive directors ensures management accountability of shareholders and reduce agency conflicts between shareholders and managers which leads to having a high debt policy (Kajanathan (2012). On the other hand, the researcher argues that the firms with a higher proportionate of non-executive directors ensure higher corporate governance and can more easily raise debt capital than other firms.

The appointment of remuneration, audit and nomination committees were recommended by Sri Lanka's code of best practice on corporate governance (2008). According to the prior literature, board committees are an important component of the board structure of companies in Sri Lanka, which affect firms' capital structure. Kajanathan (2012) found a significant positive relationship between the number of board committees and capital structure in Sri Lankan manufacturing firms. Similar to that, Bukahri \& Zakariya (2012) identified a significant relationship between the audit committee and capital structure. Even though in prior research, the impact of board committee on corporate governance on the capital structure is limited.

So, a testable hypothesis regarding non-executive directors and number of board committees with a company debt ratio is:

H2: In Sri Lanka, non-executive directors (board composition) and number of board committees are positively associated with a company debt ratio.

\section{Managerial ownership}

In emerging market firms, including Sri Lankan listed companies, they rely on managerial ownership of corporate governance practices (Manawaduge et al. 2008). The evidence regarding relationship between the managerial ownership and the capital structure is mixed. According to Hasan \& Butt (2009) and Sheikh \& Wang (2012), they found out a negative relationship between the managerial ownership and the debt ratio in Pakistan listed firms.

According to Wellalage \& Lock (2012), Sri Lankan listed companies require high debt policy with higher managerial ownership and CEO duality and identified a significant positive relationship between managerial ownership percentage and leverage ratio. Hence, this is in line with an active monitoring hypothesis, which proposes a managerial share ownership and provides greater incentives and the ability to monitor managers.

So, the testable hypothesis regarding the managerial ownership and debt ratio is:

H3: In Sri Lanka, managerial ownership is positively associated with debt ratio. 


\subsection{Operationalization and measurement of variables}

The variables used in the study, their measures and symbols are depicted in Tab. 1.

Tab. 1 - Independent and dependent variables: source - own

\begin{tabular}{|c|c|c|}
\hline Variables & Measurement & Symbols \\
\hline Debt ratio & Total debt / (Total debt + Equity) & DR \\
\hline CEO Duality & $\begin{array}{l}\text { Dummy variable “ } 0 \text { ” for combined \& “ } 1 \text { ” for separate } \\
\text { leadership }\end{array}$ & DUAL \\
\hline Board size & Number of directors & B-SIZE \\
\hline $\begin{array}{l}\text { Board } \\
\text { composition }\end{array}$ & $\begin{array}{l}\text { No. of non-executive directors / Total no. of directors } \\
\times 100\end{array}$ & $\mathrm{NON}-\mathrm{EX}$ \\
\hline Board committees & Number of board committees & B- COMMIT \\
\hline $\begin{array}{l}\text { Managerial } \\
\text { ownership }\end{array}$ & $\begin{array}{l}\text { Total no. of shares owned by members of board / Total } \\
\text { no. of shares } \times 100\end{array}$ & M-OWN \\
\hline Firm size & Natural logarithm of total assets & F- SIZE \\
\hline Return on assets & Profit before interest $\&$ tax / Total assets & ROA \\
\hline
\end{tabular}

\subsection{Sampling and data collection}

This study used secondary data extracted from the financial statements of the selected listed companies in the Colombo Stock Exchange for the years from 2009 to 2013. The sample for this study was 138 companies out of 288 listed companies in the Colombo Stock Exchange, excluding banking companies and other financial institutions. It covers 17 sectors and $66.07 \%$ of the total market capitalization of population. The present study used on line random numbers in selecting decided number of sample companies, to represent each category (sector) of the listed companies in Colombo Stock Exchange.

\subsection{Data analysis methods}

To fulfill the research objectives, the present study used descriptive statistics, paired sample ttests, and regression analysis. The descriptive statistics of mean, maximum and minimum were performed to identify the corporate governance practices. The paired sample t- test was used to determine whether there is a significant difference between two sets of means between 2009 and 2013. The linear-multiple regression analysis was used to test the effect of corporate governance on firm's capital structure.

\section{DATA ANALYSIS AND RESULTS}

\subsection{Descriptive analysis}

The descriptive statistics of the corporate governance attributes provide evidence of the extent of compliance by the firms with the Code of Best Practice on Corporate Governance in Sri Lanka (Somathilake \& Udayakumara, 2015). 
Tab. 2 - Descriptive statistics. Source: Data analysis

\begin{tabular}{|l|l|l|l|l|}
\hline & Minimum & Maximum & Mean & Std. Deviation \\
\hline Debt ratio & 0.00 & 6.80 & 0.30 & 0.37 \\
\hline Board size & 3 & 14 & 7.70 & 2.03 \\
\hline CEO duality & 0 & 1 & 0.78 & 0.41 \\
\hline Board composition & 0.17 & 1.00 & 0.68 & 0.22 \\
\hline Board committees & 0 & 3 & 1.97 & 0.56 \\
\hline Managerial ownership & 0.00 & 0.91 & 0.09 & 0.18 \\
\hline ROA & -0.54 & 0.95 & 0.10 & 0.13 \\
\hline Firm size & 4.54 & 8.13 & 6.46 & 0.66 \\
\hline
\end{tabular}

The descriptive statistics in this study show the extent to which companies in Sri Lanka complied with governance structures. Tab. 2 indicates that an average number of directors of the board in the listed companies is about 8 persons. It is consistent with the studies of Velnampy 2013), Somathilake \& Udaya Kumara (2015) and Heenetigala (2011). The mean value of board structures (CEO duality) was investigated in this study through descriptive statistics, which showed that $78 \%$ of the firms has a separate leadership style (separation of the roles of CEO and Chairman), finding is similar to Heenetigala (2011).

The mean value of the board composition shows that non-executive directors to total directors of the board is $68 \%$. It indicates that a significant number of directors are non-executive directors. It shows a fairly good presentation of board composition in Sri Lankan listed companies. This is similar with the study of Heenetigala (2011).

In order to perform better and alleviate agency conflict between shareholders and senior management, Sri Lankan companies have introduced board committees (as recommended in the Sri Lanka code of best practices 2003 and 2008), because the oversight functions of the board are primarily carried out by the board committees (Razaee, 2009). According toTab.2, average number of board committees of the listed companies in Sri Lanka is 1.97. It indicates that in generally, every listed company maintains at least two board committees. This finding is consistent with the outcomes of the study made by Velnampy (2013), Somathilake \& Udaya Kumara (2015) and Heenetigala (2011).

The mean value of selected corporate governance characteristics show that majority of listed companies in Sri Lanka are consist with the code of best practices on corporate governance (2003 \& 2008). It means that majority of listed companies have at least two non-executive directors or one third of total directors are non-executive directors, and also majority of companies have a separate leadership style (shafana, 2016). In addition to that, although most of the companies maintain all three board committees, some companies have none of such committees as per the recommendation of the code of best practices. The present study further indicate that it is better to have all relevant committees such as remuneration committee, audit committee and nomination committee to look after the activities and tasks of the companies. This is supported by Velnampy (2013), Somathilake \& Udaya Kumara (2015) and Heenetigala (2011). 
Tab. 3 - Results of Paired sample t-test. Source: Data analysis

\begin{tabular}{|l|c|c|c|c|c|}
\hline Variable & 2009 & 2013 & $\mathrm{~T}$ & $\begin{array}{c}\text { Sig. } \\
(2 \text {-tailed })\end{array}$ & $\begin{array}{c}\text { Significance } \\
\text { Level }\end{array}$ \\
\hline Board size & 7.47 & 7.99 & -4.028 & 0.00 & 0.05 \\
\hline CEO Duality & 0.77 & 0.79 & -0.904 & 0.368 & Not significant \\
\hline Board composition & 0.67 & 0.69 & -1.410 & 0.161 & Not significant \\
\hline Board committees & 1.72 & 2.17 & -7.097 & 0.000 & 0.05 \\
\hline Managerial ownership & 0.10 & 0.09 & 0.402 & 0.689 & Not significant \\
\hline
\end{tabular}

When comparing mean values of the variables of characteristics of corporate governance and the capital structure for 2009 and 2013 by using the paired sample t- test, it is revealed that variables of board size and board committees have significantly increased $(p<0.5)$. It indicates that with the introduction of the code of best practices in 2008, during the considered period of 2009 and 2013 , the number of board members and board committees of the listed companies in Sri Lanka have significantly increased. This finding is in line with Waduge (2010) and Heenetigala (2011).

\subsection{Multiple Regression Analysis}

The effect of corporate governance on firm's capital structure was tested by using the multiple regression analysis. The purpose of regression analysis is to find out the significant impact or influence of independent variable on dependent variable (Ndubisi, 2006, as cited by Achchuthan et al., 2013). In this analysis, debt ratio (the criterion for capital structure) was used as dependent variable; however, board size, CEO duality, proportion of outside directors, board committees and managerial ownership and the control variables of firm size and ROA were utilized as independent variables.

Tab. 4 - Model summary. Source: Data analysis

\begin{tabular}{|l|c|c|c|c|c|}
\hline Model & $\mathrm{R}$ & R Square & $\begin{array}{c}\text { Adjusted R } \\
\text { Square }\end{array}$ & $\begin{array}{c}\text { Standard Error } \\
\text { of the Estimate }\end{array}$ & $\begin{array}{c}\text { Durbin- } \\
\text { Watson test }\end{array}$ \\
\hline 1 & $0.255 \mathrm{a}$ & 0.065 & 0.053 & 0.3616178 & 1.206 \\
\hline
\end{tabular}

According to Tab. 4, $\mathrm{R}^{2}$ value is 0.065 . It indicates that independent variables of the model have ability to explain 6.5 percent variation of the dependent variable. The remaining 93.5 percent is influenced by other factors which are not considered for this study. So, the results from the regression model denote that the variables of corporate governance explain $6.5 \%$ variation of the capital structure of the listed companies in Sri Lanka. This result provides evidence that the corporate governance measures are not significantly influencing the capital structure decisions of the listed companies in Sri Lanka.

In the Sri Lankan context, there are few researches that have investigated the impact of corporate governance on capital structure decisions and also found mix results (Shafna, 2016). Furthermore, many of them were based on the manufacturing sector companies and generalize the results to all listed companies in Sri Lanka (shafna, 2016). Kajanathan (2012) found out that 34\% 
impact of the corporate governance characteristics on the capital structure in the listed manufacturing companies in Sri Lanka for the period of 2009 to 2011. Somathilake \& udaya Kumara (2015) also found a significant relationship between the corporate governance and the capital structure of the selected manufacturing companies for the sample period of 2011 to 2013.

The findings of the present study were supported by the studies of Peiris \& Fernando (2013) and Ravivathani \& Danoshana (2014). Peiris \& Fernando (2013) stated that the corporate governance characteristics have no significant effect on the capital structure decisions of the listed non- financial companies in Sri Lanka. Likewise, same results were identified by Ravivathani \& Danoshana (2014).

Tab. 5 - Anova table in regression analysis. Source: Data analysis

\begin{tabular}{|l|l|l|l|l|l|l|}
\hline \multicolumn{2}{|l|}{ Model } & Sum of Squares & Df & Mean Square & F & Sig. \\
\hline \multirow{3}{*}{1} & Regression & 4.952 & 7 & 0.707 & 5.410 & $.000 \mathrm{a}$ \\
\cline { 2 - 8 } & Residual & 71.137 & 544 & 0.131 & & \\
\cline { 2 - 8 } & Total & 76.089 & 551 & & & \\
\hline
\end{tabular}

The F-ratio in the ANOVA table (Tab. 5) proves the validity of the estimated models. The table shows that the independent variables statistically significant predict the dependent variable $(F$ $=5.410, p<0.005)$.

Tab. 6 - Table of Coefficients. Source: Data Analysis

\begin{tabular}{|c|c|c|c|c|c|c|c|}
\hline \multirow{2}{*}{ Model } & \multicolumn{2}{|c|}{$\begin{array}{c}\text { Unstandardized } \\
\text { Coefficients }\end{array}$} & \multirow{2}{*}{$\begin{array}{c}\text { Standardized } \\
\text { Coefficients }\end{array}$} & \multirow{2}{*}{$\mathrm{T}$} & \multirow{2}{*}{ Sig. } & \multicolumn{2}{|c|}{$\begin{array}{c}\text { Collinearity } \\
\text { Statistics }\end{array}$} \\
\hline & B & $\begin{array}{l}\text { Std. } \\
\text { Error }\end{array}$ & & & & Tolerance & VIF \\
\hline (Constant) & 0.257 & 0.179 & & 1.434 & 0.152 & & \\
\hline Board size & -0.022 & 0.140 & -0.007 & -0.156 & 0.876 & 0.843 & 1.186 \\
\hline Duality & 0.009 & 0.038 & 0.010 & 0.231 & 0.817 & 0.972 & 1.029 \\
\hline $\begin{array}{l}\text { Non-Exe. } \\
\text { Directors }\end{array}$ & 0.264 & 0.070 & 0.158 & 3.743 & 0.000 & 0.963 & 1.039 \\
\hline $\begin{array}{l}\text { Board Com- } \\
\text { mittees }\end{array}$ & -0.074 & 0.031 & -0.112 & -2.398 & 0.017 & 0.784 & 1.276 \\
\hline $\begin{array}{l}\text { Manag. own- } \\
\text { ership }\end{array}$ & -0.057 & 0.086 & -0.028 & -0.658 & 0.511 & 0.961 & 1.041 \\
\hline ROA & -0.366 & 0.119 & -0.131 & -3.071 & 0.002 & 0.950 & 1.053 \\
\hline Firm size & 0.004 & 0.012 & 0.017 & 0.352 & 0.725 & 0.737 & 1.358 \\
\hline
\end{tabular}

For the purpose of generating reliable results and generalizing the model, multicollinearity and test of auto correlation were carried out. The results of this analysis are presented in Tab. 6. Ac- 
cording to the table, since all VIF values are less than 10 there is no issue of multi-co Linearity between the independent variables. The Durbin Watson test was used to detect the auto correlation. Tab. 4 shows that Durbin Watson value is less than 3, which is indicating that there is no autocorrelation.

Three hypotheses were formulated based on prior literature. According to the results, some hypotheses were supported and some were not supported by the findings. The regression results reported in Tab. 6 reveal that the board size, leadership structure and managerial ownership variables do not significantly affect the debt ratio $(\mathrm{p}>0.05)$. The variables of proportion of nonexecutive directors and board committees have been identified as important variables which affect decisions on the capital structure $(\mathrm{P}<0.05)$.

According to the findings, a positive relationship between proportion of non-executive directors and leverage position of firms was identified, and this hypothesis is supported by the findings, whereas a significant negative relationship was identified between board committees and leverage position of the firm.

\section{CONCLUSION AND MANAGERIAL IMPLICATION}

Considering the competitiveness of the business world today, this study empirically examined the practices of corporate governance and the impact of corporate governance on capital structure decisions of non-financial listed companies in Sri Lanka for the period of 2009 to 2013 by using the descriptive statistics, Paired Sample t test and multiple regression analysis. According to the descriptive statistics, it is concluded that the listed companies under the Colombo Stock Exchange (CSE) comply well with the recommendations of corporate governance practices.

The regression results reveal that the representation of non-executive directors and variable of board committees are significantly related to capital structure. This is in line with the findings of Kajanathan (2012). The proportion of non-executive directors shows a positive impact on a firm debt ratio. One possible explanation of this situation may be when firms have more outside directors, they increase protection against uncertainties and this increases the firm's ability to raise external debt. The above mentioned argument is empirically supported by Kajanathan (2012), Abor (2007) and Berger et al. (1997), whereas the number of board committees shows a negative impact on leverage position. The negative relation shows that the board having all three committees avoid taking a large amount of debt because of strong monitoring. However, the variables of board size and CEO/Chair duality have no significant effect on the leverage position of the firms. On the other hand, managerial ownership negatively related to leverage ratio indicating that the concentration of ownership induces the managers to lower the gearing levels but this impact is statistically insignificant (Wellalage \& Lock, 2012).

Finally, the study has identified that except board composition and board committees, other corporate governance practices are not significantly affected by capital structure decisions. This is in line with the findings of Somathilake \& Udayakumara (2015).

This study reported that the variable of board composition (having more independent non-executive directors of the board) significantly effects financial decisions. Non-executive directors 
play supervisory and balancing roles, controlling the activities of the executive directors and the board in general. In an attempt to maintain well-balanced independent boards, this study and findings of prior researches propose that the code of best practices should include the boards to have at least fifty percent of non-executive directors, not one third as stated in the Sri Lanka code of best practices on corporate governance (2008). This is supported by Kajanathan (2012) \& Velnampy (2013). In addition to that, the regression results reveal that the variable of board committee significantly effects the financial decisions but the average number of committees which companies maintain is two. It is better to have all relevant committees as per the code of best practices (2008), such as remuneration committee, audit committee and nomination committee to look after the activities and tasks of the companies. These recommendations are in line with Waduge, 2010. According to recommendations of Waduge, (2010), the corporate governance can be improved in Sri Lanka in three aspects. Among them, an important one is a greater independence and authority needs to be granted to oversight committees within the firm. Further, in particular, the roles and functions of the remuneration and audit committees need to be strengthened.

On the other hand, financial decisions are directly affected by the risk condition of the firms. In order to have a clear understanding of the risk and to manage the risks identified in a satisfactory manner, it was proposed to appoint risk management committees (Kajanathan, 2012 \& Velnampy, 2013).

\section{References}

1. Abor, J. (2007). Corporate governance and financing decisions of Ghanaian listed firms. Corporate Governance. The international journal of business in society, 7(1), 83-92. http://dx.doi. $\operatorname{org} / 10.1108 / 1472070071072713$.

2. Achchuthan, R., Kajanathan, R., and Sivathasan, N. (2013). Corporate governance practices and capital structure: A case in Sri Lanka. International journal of business and management 21(8), 114 -125. http://dx.doi.org/10.5539/ijbm.v8n21p114.

3. Ahmadpour, A., Samim, I.A.J. and Golmohammadi, H. (2012). Corporate Governance and Capital Structure: Evidence from Tehran Stock Exchange. Middle-East Journal of Scientific Research, 11 (4), 531-535.

4. Ajanthan, A. (2013). Impact of corporate governance practices on firm capital structure and profitability: a study of selected hotels and restaurant companies in Sri Lanka. Research journal of finance and Accounting, 10(4), 115-126.

5. Bancel. F. and Mittoo, U. R. (2004). Cross-Country Determinants of Capital Structure Choice. A Survey of European Firms Financial Management, 33(4).

6. Berger, P. G., Ofek, E. and Yermack, D. L. (1997). Managerial Entrenchment and Capital structure decisions. Journal of Finance, 52(4), 1411-1438.

7. Bodaghi, A. and Ahmadpour, A. (2010). The Effect of Corporate Governance and Ownership Structure on Capital Structure of Iranian Listed Companies: 7 th International Conference on Enterprise Systems, Accounting and Logistics (7th ICESAL 2010) 28-29 June 2010, Rhodes Island, Greece. 
8. Bukari, M. K. A. S. and Zakaria R. M. A. B. (2012). Corporate governance practices and their impact on firms' capital structure: case of Pakistan textile sector. University of Multon Pakistan.

9. Cadbury, A. (1992). Report on the Committee on the Financial Aspects of Corporate Governance. Gee, London.

10. Claessens, S. (2001). Corporate governance and development. Global Corporate Governance Forum 1, Focus o1. Retrieved from: www.gcgf.org.

11. Coloambage, S. (2007). Consistency and controversy in corporate financing practices. Studies in Economics and Finance, 24(1), 51-71.

12. Ganiyu, Y.O.G. and Abiodun, B.Y. (2012). The impact of corporate governance on capital structure decision of Nigerian firms: Research journal in organizational Psychology and Education studies. 1(2) 121-128.

13. Gill, A., Biger, N., Mand, H. S., and Shah, C. (2012). Corporate governance and Capital structure of small business service firms in India. International journal of economic and finance, 4 (8), 83-92 http://dx.doi.org/10.5539/ijef.v4n8p83.

14. Graham, J. and Harvey, C. (2001). The Theory and Practice of Corporate Finance: Evidence from the Field. Journal of Financial Economics, 60, 187-243.

15. Hassan, A. and Butt, S. A. (2009), Impact of Ownership Structure and Corporate governance on Capital Structure of Pakistani Listed Companies. International Journal of Business and Management, 4(2), 50-57. Retrieved from: http://ssrn.com/abstract=1732511. www.ecsenet.org/journal.html.

16. Heenatigala, K. (2011). Corporate governance practices and firm performance of listed companies in Sri Lanka. Thesis submitted in fulfilment of the requirement of the degree of doctorate. Victoria graduate school, Melbourne.

17. ICASL (2003). Code of Best Practice on Corporate Governance. The Institute of Chartered Accountants of Sri Lanka, Colombo.

18. ICASL and SEC of Sri Lanka (2008). Code of Best Practice on Corporate Governance, Colombo.

19. Kajananthan, R. (2012). Effect of Corporate Governance on Capital Structure, Case of the Sri Lankan Listed Manufacturing Companies. Journal of Arts. Sciences \& Commerce, 3(4), 63-71.

20. Magdalena, R. (2012). Influence of Corporate Governance on Capital Structure Decision: Evidence from Indonesian Capital Market. World Review of Business Research, 2(4), 37 - 49.

21. Manawaduge, A., Zoysa, A. D. and Rudkin, K. (2008). Performance implication of Ownership structure and ownership concentration: Evidence from Sri Lankan firms. Performance management conference (1-12). Retrieved from: http://ro-uow.edu.au/ commpapers/2395.

22. Mulili, M. B. and Wong, P. (2011). Corporate Governance Practices in Developing Countries, the Case in Kenya. International Journal of Business Administration, 2(1), 14-27. https://doi.org/10.5430/:jba.v2n1p14.

23. Pass, C. (2004). Corporate Governance and the Role of non-executive Directors in Large UK Companies: an Empirical Study, Corporate Governance. The International journal of Business in society, 4 (2), 52-63. http://dx.doi.org/10.1108/ 14720700410534976. 
24. Peiris J. M. P. D. and Fernando S. P. K. (2013). The impact of corporate governance on capital structure decisions. First annual student's research symposium. Faculty of commerce \& management studies. University of Kelaniya, Sri Lanka., p36.

25. Ravivathani, T. \& Danoshana S. (2014). The impact of corporate governance practices on capital structure: Empirical study on the listed companies in Sri Lanka. Asia pacific journal of marketing and management review, 3(2).

26. Rezaee, Z. (2009). Corporate Governance and Ethics. John Wiley \& Sons, Inc, USA. Retrieved from: http://www.wiley.com/WileyCDA/WileyTitle/productCd-EHEP000835.html.

27. Saad, N. M. (2010). Corporate Governance Compliance and the Effects to Capital Structure in Malaysia. International Journal of Economics and Finance, 2(1). http://citeseerx.ist. psu.edu/viewdoc/doi=10.1.1.633.8734.

28. Samarakoon, L. P. (1999). The capital structure of Sri Lankan companies. Sri Lankan Journal of Management, $4(1$ \& 2).

29. Shafana, M. A. C. N. (2016). Board of directors' characteristics impact on capital structure decisions: Evidence from Top 50 turnover non- financial companies listed on the Colombo Stock exchange. International journal of science research. Retrieved from: www.ijsr.net doi:10.21275/ART20161970.

30. Sheikh, N.A.S. and Wang, Z. (2012). Effects of corporate governance on capital structure: empirical evidence from Pakistan. Corporate governance. The International journal of Business in society, 12(5), 629-641. http.//dx.doi.org/10.1108/14720701211275569.

31. Sobhan, F. and Wendy, W. (2003). A comparative analysis of corporate governance in South Asia; charting a roadmap for Bangladesh. Bangladesh enterprise. Retrieved from: www.bei-bd.org

32. Somathilake, H. M. D. N. and Udayakumara, K. G. A. (2015).The effect of corporate governance attributes on capital structure: An empirical evidence from listed manufacturing companies in Colombo Stock Exchange. International research symposium, Rajarata University of Sri Lanka.

33. Panos, L. J. (2005). Corporate Governance in Greece: Developments and Policy Implications. Corporate Governance, 5 (1) 15-30. Retrieved from: https://core.ac.uk/ download/pdf/9315261.pdf.

34. Thomson, L. M. and Bureau, E. T. (2009). Articles about Corporate governance-economic times. Retrieved from: http://articlea.economictimes.indiatimes.com.

35. Vakilifard, H. R., Gerayli, M. S., Yanesari, A. M. and Ma'atoofi, A. R. (2011). Effect of Corporate Governance on Capital Structure: Case of the Iranian Listed Firms. European Journal of Economics. Retrieved from: http://www.eurojournals.com.

36. Velnampy. T, (2006). An empirical study on application of Altman original bankruptcy forecasting model in Sri Lankan companies. Journal of Management, Sai Ram Institute of Management,1(1). Retrieved from: http://hdi.handle.net/123456789/670.

37. Velnampy. T. and Aloy Niresh. J. (2012), Corporate governance and performance. Global Journal of Management and Business Research, 12(13) 66-73.

38. Velnampy, T. (2013). Corporate governance and firm performance. A study of Sri Lankan manufacturing companies. Journal of economics and sustainable development, 4(3). Retrieved from: http;//www.researchgate.net/249341798. 
39. Waduge, C. S. D. S. L. (2010). Corporate governance best practices and new listing rules in Sri Lanka.: Proceeding of the 2nd international on corporate governance. Retrieved from: http;//www.academia.edu/1521493.

40. Wellalage N. and Locke (2012). Corporate governance and capital structure decisions of Sri Lankan listed firms. Global review of business and economic research, 8 (1) 157-169.

\section{Contact Information}

S. Bulathsinhalage, $M$ com

Advanced Technological Institute

Gampaha, Sri Lanka

E-mail:Siromibulathsinbalage@yahoo.com

C. Pathirawasam, PhD

Department of Commerce \& Financial Management

Faculty of Commerce and Management Studies

University of Kelaniya, Sri Lanka.

E-mail:patbi3@yahoo.com 